Goldschmidt 2021 Abstract

https://doi.org/10.7185/gold2021.4887

\section{Mesoproterozoic high-grade metamorphism of Laurentian crust recorded in the subducted crustal rocks of western Tasmania: decoding an obscured polymetamorphic record using garnet laser ablation ICP- MS/MS Lu-Hf geochronology}

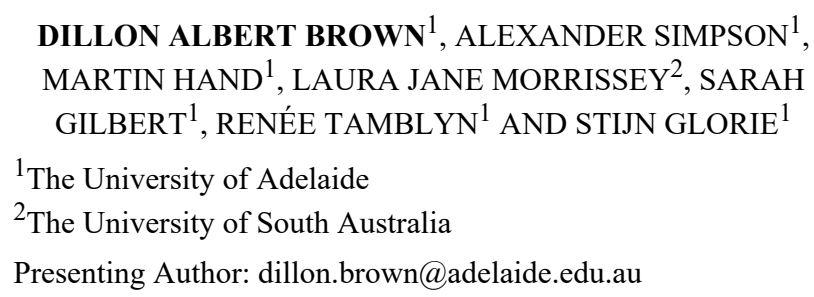

In cases where metamorphic rocks preserve superimposed mineral assemblages, recorded pressure-temperature $(P-T)$ histories are often difficult to differentiate. Here, we use the recently developed in-situ laser ablation ICP-MS/MS Lu-Hf geochronology method (see companion abstract, Simpson et al., session 6d) to demonstrate that garnets from crustal rocks in western Tasmania record previously unrecognised high-grade metamorphism that directly correlates in age with metamorphism in western Laurentia. Coarse-grained garnets in amphibolitefacies metapelites yield in-situ derived $\mathrm{Lu}-\mathrm{Hf}$ ages between $\mathrm{c}$. 1360-1250 Ma (with most ages less than c. $1300 \mathrm{Ma}$ ), highlighting a record of Mesoproterozoic-aged high-grade metamorphism which has been largely obscured by metamorphic overprinting during Cambrian-aged subduction along the East Gondwana margin. Furthermore, results from monazite $\mathrm{U}-\mathrm{Pb}$ geochronology and trace-element chemistry reveal a possible earlier metamorphic event at c. 1385 Ma that did not involve the growth of garnet. With recent detrital zircon age results strongly indicating that the protoliths to the western Tasmanian rocks were sourced from western Laurentia, we propose that the record of Mesoproterozoic-aged metamorphism identified in the western Tasmanian metapelites is in fact representative of highgrade metamorphism of western Laurentian crust, which was separated from Laurentia in the Neoproterozoic and incorporated into the East Gondwana subduction system during the Cambrian.

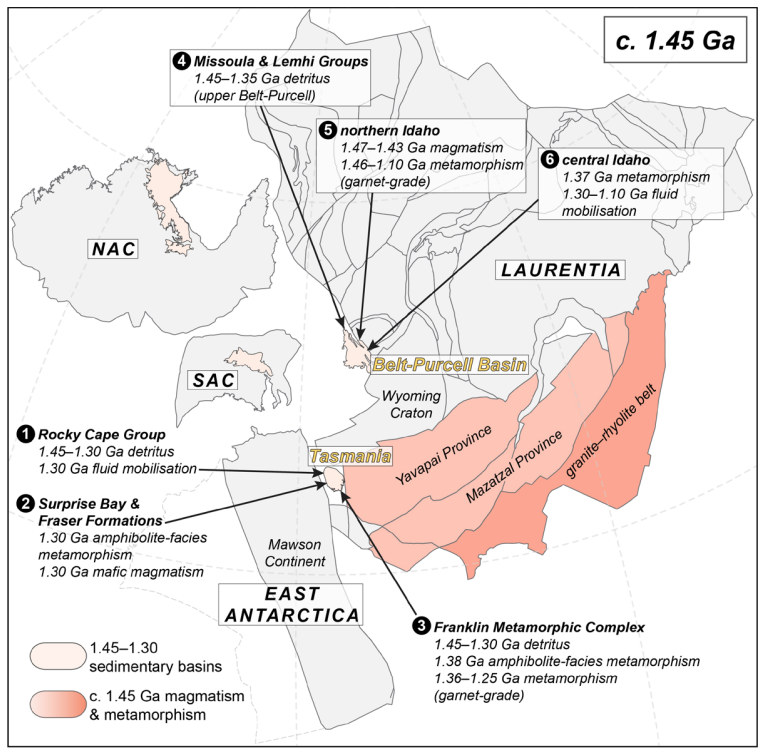

